\title{
Arabinogalactan Proteins Occur in the Free-Living Cyanobacterium Genus Nostoc and in Plant-Nostoc Symbioses
}

\author{
Owen Jackson, Oliver Taylor, David G. Adams, and J. Paul Knox \\ Centre for Plant Sciences, Faculty of Biological Sciences, University of Leeds, Leeds LS2 9JT, U.K. \\ Submitted 26 April 2012. Accepted 31 May 2012.
}

\begin{abstract}
Arabinogalactan proteins (AGP) are a diverse family of proteoglycans associated with the cell surfaces of plants. AGP have been implicated in a wide variety of plant cell processes, including signaling in symbioses. This study investigates the existence of putative AGP in free-living cyanobacterial cultures of the nitrogen-fixing, filamentous cyanobacteria Nostoc punctiforme and Nostoc sp. strain LBG1 and at the symbiotic interface in the symbioses between Nostoc spp. and two host plants, the angiosperm Gunnera manicata (in which the cyanobacterium is intracellular) and the liverwort Blasia pusilla (in which the cyanobacterium is extracellular). Enzyme-linked immunosorbent assay, immunoblotting, and immunofluorescence analyses demonstrated that three AGP glycan epitopes (recognized by monoclonal antibodies LM14, MAC207, and LM2) are present in free-living Nostoc cyanobacterial species. The same three AGP glycan epitopes are present at the Gunnera-Nostoc symbiotic interface and the LM2 epitope is detected during the establishment of the Blasia-Nostoc symbiosis. Bioinformatic analysis of the $N$. punctiforme genome identified five putative AGP core proteins that are representative of AGP classes found in plants. These results suggest a possible involvement of AGP in cyanobacterial-plant symbioses and are also suggestive of a cyanobacterial origin of AGP.
\end{abstract}

Cyanobacteria are known to enter into a wide variety of symbioses (Bergman et al. 2008), including those with the water fern genus Azolla (Lechno-Yossef and Nierzwicki-Bauer 2002), lichens (Rikkinen 2002), the fungus genus Geosiphon (Kluge et al. 2002), hornworts, and liverworts, including Anthoceros punctatus and Blasia pusilla (Adams and Duggan 2008, 2011) and cycads (Costa and Lindblad 2002). Their ability to fix atmospheric nitrogen is often utilized in these relationships, providing their host with a source of combined nitrogen. Many cyanobacterial species capable of nitrogen fixation do so via specialized cells, known as heterocysts, which have a thickened cell wall and provide a microaerobic environment for the functioning of the highly oxygen-sensitive enzyme nitrogenase, which is responsible for the conversion of $\mathrm{N}_{2}$ to $\mathrm{NH}_{3}$. Heterocyst structure and function have been recently reviewed (Flores and Herrero 2010).

The symbiosis between the cyanobacteria of the genus Nostoc and the angiosperm genus Gunnera is unique because the cya-

Corresponding author: J. P. Knox: E-mail: j.p.knox@leeds.ac.uk

* The $\boldsymbol{e}$-Xtra logo stands for "electronic extra" and indicates that Figures $2,3,5$, and 6 appear in color online. nobiont forms colonies within plant cells in specialized gland structures at the base of each leaf petiole (Bergman 2002). The relationship is mutually beneficial, the plant receiving fixed nitrogen from the bacterium (Silvester and Smith 1969; Silvester et al. 1996) and the bacterium receiving fixed carbon from the plant (Black et al. 2002), possibly in the form of fructose (Ekman et al. 2006). The relationship is facultative, in that both the plant and the bacterium may be cultured separately (Silvester and McNamara 1976) although all species of Gunnera investigated in the wild contain Nostoc spp. as an intracellular symbiont (Osborne et al. 1991).

Gunnera spp. exert a high level of selectivity over the bacterial partners; only Nostoc spp. are found as symbionts, and only those strains capable of high levels of differentiation into hormogonia, which are specialized motile filaments that lack heterocysts and which are the infective agents in cyanobacteria-plant symbioses (Adams and Duggan 2011; Bonnett and Silvester 1981). Nonetheless, the ability to develop heterocysts and hormogonia is not enough to guarantee symbiotic competence-some strains are capable of both yet still do not generate stable symbioses with Gunnera spp. (Bonnett and Silvester 1981; Johansson and Bergman 1994). A second symbiosis studied in the work presented here is that between Nostoc spp. and the liverwort B. pusilla in which, unlike Gunnera spp., the cyanobiont does not enter the cells of the host plant but, instead, is contained within dome-shaped structures, known as auricles, on the ventral surface of the thallus (Adams 2002; Adams and Duggan 2008, 2011). The cyanobiont occupies the space between the auricle wall and the central slime papilla; an outer papilla is found adjacent but external to the auricle.

Arabinogalactan proteins (AGP) are a very diverse group of proteoglycans generally found associated with plant cell surfaces (Ellis et al. 2010; Nothnagel 1997; Seifert and Roberts 2007; Showalter 2001). They are rich in hydroxyproline and are highly glycosylated, with approximately $90 \%$ of the total molecular mass (usually between 60 and $300 \mathrm{kDa}$ ) (Nothnagel 1997) being attributed to the carbohydrate portion of the molecule (Showalter 1993). The glycan components of plant AGP are highly heterogeneous and contain arabinose and galactose along with rhamnose, glucuronic acid, and other sugars. The AGP glycan is linked by $O$-glycosylation to a small polypeptide core which generally constitutes less than $10 \%$ of the molecular mass (Ellis et al. 2010; Gaspar et al. 2001). The most abundant amino acids in the polypeptide core are proline (hydroxyproline), alanine, serine, threonine (collectively termed PAST) (Schultz et al. 2000).

AGP are divided into several families based on their protein cores (Gaspar et al. 2001; Seifert and Roberts 2007). Classical AGP core proteins consist of a region rich in PAST along with 
an N-terminal signal peptide and a hydrophobic C-terminal domain signal for the addition of a GPI anchor (Showalter 2001). Arabinogalactan (AG) peptides are a subset of the classical AGP - they consist of the same three regions but their PAST-rich region is truncated, and the entire peptide is typically less than 75 amino acids in length (Schultz et al. 2002). The fasciclin-like AGP (FLA) are a group of nonclassical AGP that differ from the classical AGP only in that they contain conserved fasciclin domains within the mature peptide (Faik et al. 2006; Johnson et al. 2003).

Some prokaryotes, such as mycobacteria, do have an AG component in cell envelopes along with mycolic acid and a peptidoglycan complex (or, confusingly, the mycolyl AG-peptidoglycan complex), which is covalently linked to their cell membrane (Crick et al. 2001). It should be noted that, whereas this fraction of the mycobacterium cell membrane shares the designation "AG" with the plant AGP, these are very different structures, with the arabinose being D-arabinose (whereas in plant AG the arabinose is largely L-arabinose). Hence, although there may be a designative link between the names of plant and bacterial AG, there is no evidence of the two being structurally or developmentally linked.

AGP have been implicated in several processes in plant cells: cell division, cell expansion, programmed cell death, and intercellular signaling, including plant-microbe interactions (Seifert and Roberts 2007). Endoglycanase enzymes may cleave off short oligosaccharides from the extended AGP structure, and it has been proposed that these may act as longrange signaling molecules, because they would be small and soluble, making them far more mobile than the entire AGP (Seifert and Roberts, 2007; van Hengel et al. 2001). This would allow AGP to have an effect on cell processes within and between cells and, in part, explain their wide-ranging potential roles. AGP have been shown to be present at the symbiotic interface in the Frankia-Alnus symbiosis (Berry et al. 2002), as well as being involved in the symbiosis between the arbuscular mycorrhizal fungus Glomus intraradices and the legume Medicago truncatula (Schultz and Harrison 2008).

Previous observations have raised the possibility that AGP may play a role in the Gunnera-Nostoc symbiosis (Rasmussen et al. 1996; Snogerup 1997) and plant-cyanobacterial symbioses in general. To study this further, we have made use of sets of monoclonal antibodies, each with a different binding site within the complex glycan structures of AGP, and which are used to investigate AGP occurrence at plant cell surfaces (Berry et al. 2002; Knox 2008; Lee et al. 2005). Here, we report the presence of specific AGP glycan epitopes in both freeliving partners of the Gunnera-Nostoc and Blasia-Nostoc symbioses and at the interfaces between host cells and cyanobacteria. Moreover, we provide evidence from the genome of Nostoc punctiforme for the presence of putative AGP core proteins representative of the classical AGP, AG peptide, and FLA classes of AGP protein structures found in plants.

\section{RESULTS}

Free-living cyanobacterial strains express AGP epitopes.

To lay the foundation for an analysis of AGP in plant-cyanobacterial symbioses, the presence of AGP epitopes was assessed in two free-living and symbiotically competent Nostoc strains and their growth media. When eight monoclonal antibodies directed to distinct glycan epitopes of plant AGP were screened by enzyme-linked immunosorbent assay (ELISA), three were found to bind to material obtained from lysed cells of $N$. punctiforme and Nostoc LBG1 (Fig. 1A). The monoclonal antibodies LM14 (Moller et al. 2008) and MAC207 (Pennell et al. 1989) bound effectively to material from $N$. punctiforme and showed some preferential occurrence in cell material grown in the presence of nitrate. Recognition of these epitopes in LBG1 was significantly lower, although again showing preference for cells grown in the presence of nitrate (Fig. 1A). By contrast, the LM2 AGP glycan epitope (Smallwood et al. 1996) was not detected in $N$. punctiforme cell material but was present in LBG1 cells and was also more abundant in cells when grown in the presence of nitrate. These results were explored further through immunoblotting of 20-fold concentrated, used growth media from the same two cyanobacterial strains (Fig. 1B). All three monoclonal antibodies bound to some high molecular weight smears $>200 \mathrm{kDa}$, in accordance
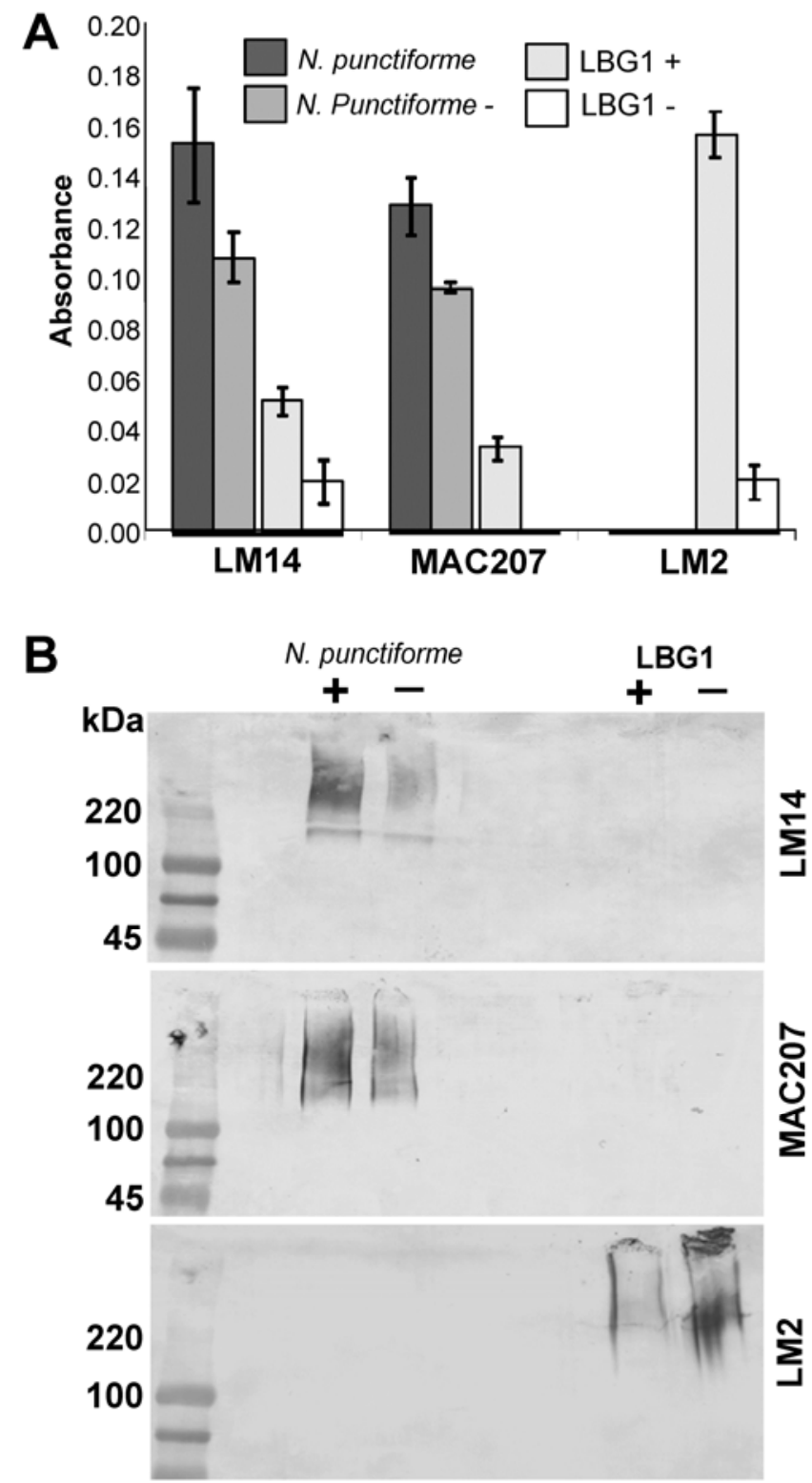

Fig. 1. Detection of arabinogalactan protein (AGP) epitopes in free-living Nostoc spp. A, Enzyme-linked immunosorbent assay analysis of lysed cell suspensions of cyanobacterial strains Nostoc punctiforme and Nostoc LBG1 with anti-AGP antibodies LM14, MAC207, and LM2. Samples grown in the presence $(+)$ or absence $(-)$ of nitrate and equalized to chlorophyll a at $1 \mu \mathrm{g} \mathrm{ml}^{-1}$ for coating of microtiter plates. Error bars indicate standard error of the mean of three replicates. B, Immunoblots of $N$. punctiforme and Nostoc LBG1 growth media from cultures grown with (+) or without (-) a nitrate source with anti-AGP monoclonal antibodies LM14, MAC207, and LM2. In both sets of analyses, LM14 and MAC207 show a preference for $N$. punctiforme cells or exudates and LM2 for LBG1 cells or exudates. 
with the properties of plant AGP when run on sodium dodecyl sulfate (SDS) polyacrylamide gels. The differential recognition of media reflected that of lysed cell material observed in ELISA analysis, in that LM14 and MAC207 bound specifically to molecules in the media of $N$. punctiforme and LM2 to material from the media of Nostoc LBG1.

These observations indicate that specific epitopes, known to be present in some plant AGP, were present in the cells and growth media of free-living Nostoc spp.; that the epitopes were carried by high molecular weight molecules with properties equivalent to those of plant AGP; that there was a differential occurrence of specific epitopes (recognized by MAC207 or LM14 versus LM2) in the two strains of Nostoc; and that there was a tendency to detect quantitatively more AGP epitopes in media obtained from Nostoc strains grown in the presence of nitrate.

Indirect immunofluorescence microscopy was used to further investigate the occurrence of the LM14, MAC207, and LM2 AGP epitopes in Nostoc strains (Fig. 2). Five other AGPspecific antibodies (JIM4 and JIM13 to -16) did not bind to Nostoc cells and JIM4 was used as a negative control (Fig. 2). In the case of LM14 and MAC207, antibody binding to filaments of $N$. punctiforme was localized to the cell surfaces of vegetative cells in filaments or the extracellular material known to coat them. Antibody binding was generally most abundant in vegetative cells adjacent to heterocysts but absent from the heterocysts themselves (Fig. 2A and B). The epitope recognized by the LM2 antibody was also detected in Nostoc LBG1 at the surface of filaments (Fig. 2C). At the surface of Nostoc LBG1 filaments, the LM14 or MAC207 epitopes were only observed at very low levels and were often not observed at all, and the same was true for $N$. punctiforme filaments with LM2 (data not shown). This supports the conclusions of ELISA analyses that AGP glycan epitopes are present in these organisms.

Cultures of Nostoc LBG1 were induced to form hormogonia by transferring exponentially growing cultures from media lacking nitrate (but supplemented with $35 \mathrm{mM}$ glucose) into the same medium lacking glucose. The three anti-AGP antibodies identified previously as interacting with the two Nostoc spp. were used to detect AGP epitopes at the surface of LBG1 hormogonia (Fig. 3). Only bound LM2 and its epitope was associated with the exopolysaccharide sheath known to coat cyanobacterial filaments (Pereira et al. 2009).

\section{In silico analysis indicates that the $N$. punctiforme genome encodes proteins with the characteristics of AGP core proteins.}

Previous studies have outlined a method for identifying AGP protein-coding sequences in Arabidopsis (Schultz et al. 2002; Showalter et al. 2010) and in Triticum aestivum and Oryza sativa (Faik et al. 2006) genomes. It should be noted that these studies were all undertaken in plants and, if AGP core protein sequences are present in cyanobacteria, these may have characteristics very different from those of plants; however, it was considered that the use of these techniques was a starting point from which further analysis could be undertaken. Application of these methods to the $N$. punctiforme genome led to the identification of several proteins that appear to possess some of the unusual characteristics of AGP core proteins; for example, regions rich in PAST (found in PA/PT/PS repeats) and a signal peptide targeting the protein to the cell surface. Schematic outlines of the structures of these putative Nostoc AGP core proteins are shown in Figure 4. Regions containing the sequence ([AST]-P-X $\left.{ }_{(0,10)}-[\mathrm{AST}]-\mathrm{P}\right)$, where [AST]-P motifs are separated by less than 11 other amino acids, are good candidates for glycomodules because this sequence may be readily arabi- noglycosylated (Schultz et al. 2002). All the candidate protein sequences contain these regions (Table 1).

Putative representatives of all three classes of AGP core protein sequences known for plant AGP can be identified in the $N$. punctiforme genome. Of the five candidate putative proteins identified, two (NPUN_F0888 and NPUN_R0902) most closely resemble the classical AGP family, having an N-terminal signal sequence (targeting the protein to the cyanobacterial cell wall), a glycomodule rich in PAST, and no fasciclin domains (Fig. 4) (Schultz et al. 2000). One protein (NPUN_F4498) resembles an AG peptide, being between 50 and 75 amino acids in length and $>35 \%$ PAST, along with a signal peptide (Fig. 4) (Schultz et al. 2002). The other two proteins (NPUN_ R4210 and NPUN_F4094) resemble FLA, in that they contain fasciclin domains along with the characteristic PAST-rich glycomodules and the signal peptide (Fig. 4) (Johnson et al. 2003). It should be noted that, whereas some plant AGP contain GPI anchors, debate continues as to whether GPI anchors have been found in prokaryotes (Chatterjee and Mayor 2001; Chungjatupornchai and Fa-aroonsawat 2009) and, hence, they may not be expected to be found in the proteins identified here.

The two putative FLA identified by this study contain several recognized domains as identified by InterProScan (Zdobnov and Apweiler 2001). NPUN_F4094 contains a domain with homology to the FAS1 fasciclin domain family. The same region also shows homology to the FimH-like protein family (PANTHER protein subfamily PTHR10900:SF8) involved in cell adhesion. NPUN_R4210 contains regions of the same families identified for NPUN_F4094, along with an S-layer homology region (InterPro family IPR001119), which form layers of glycoproteins known to coat bacterial surfaces (Mesnage et al. 2000). Both putative FLA identified here have been previously identified by proteomic studies of the $N$. punctiforme proteome. NPUN F4094 (labeled by its accession number, ZP_00111758) was identified as a protein involved in cell motility, secretion, or cell envelope biogenesis in the soluble cell fraction of $N$. punctiforme cells grown in the absence of a nitrate source, demonstrating the presence in vivo of this protein in the proteome (Ran et al. 2007). It should be noted, however, that this attribution of function was based on sequence analysis alone. Similarly, NPUN_R4210 (labeled by its accession number, ZP_00108174) was found to be one of only four surface- or membrane-associated proteins upregulated in Nostoc spp. isolated from Gunnera glands (Ekman et al. 2006). Again, these were designated as membrane-associated via sequence analysis rather than a direct attribution of function. Both putative FLA contain regions resembling AG glycomodules containing noncontiguous [AST]-P repeats, as well as the distinctive $\left([\mathrm{AST}]-\mathrm{P}-\mathrm{X}_{(0,10)}-[\mathrm{AST}]-\mathrm{P}\right)_{\mathrm{x}}$ repeats, as used to identify putative AGP (Table 1) (Faik et al. 2006; Showalter et al. 2010).

The two classical AGP-like proteins identified here also have high numbers of characteristic [AST]-P and ([AST]-P$\left.\left.\mathrm{X}_{(0,10)}\right)^{-}[\mathrm{AST}]-\mathrm{P}\right)_{\mathrm{X}}$ repeats. NPUN_R0902 contains a signal peptide identified by InterProScan, suggesting that the protein is located in the cell membrane. This would be expected in an AGP acting as an extracellular signaling molecule. NPUN F0888 contains two recognized domains: an XGLTT gated calcium channel region (ProDom family ID PD003992) and a cell wall peptidoglycan anchor (PD153432), as identified by InterProScan (Zdobnov and Apweiler 2001). These domains suggest that the protein is localized to the cell wall or envelope.

The predicted AG peptide, NPUN_F4498, contains a signal peptide region and overlapping transmembrane domain. Schultz and associates (2002) suggest that AG peptides can only be defined if they contain two or more AP/SP motifs in the mature protein. SignalP (Bendtsen et al. 2004) predicts the cleavage of the signal peptide either at position $25-26$ or $35-36$ - this 

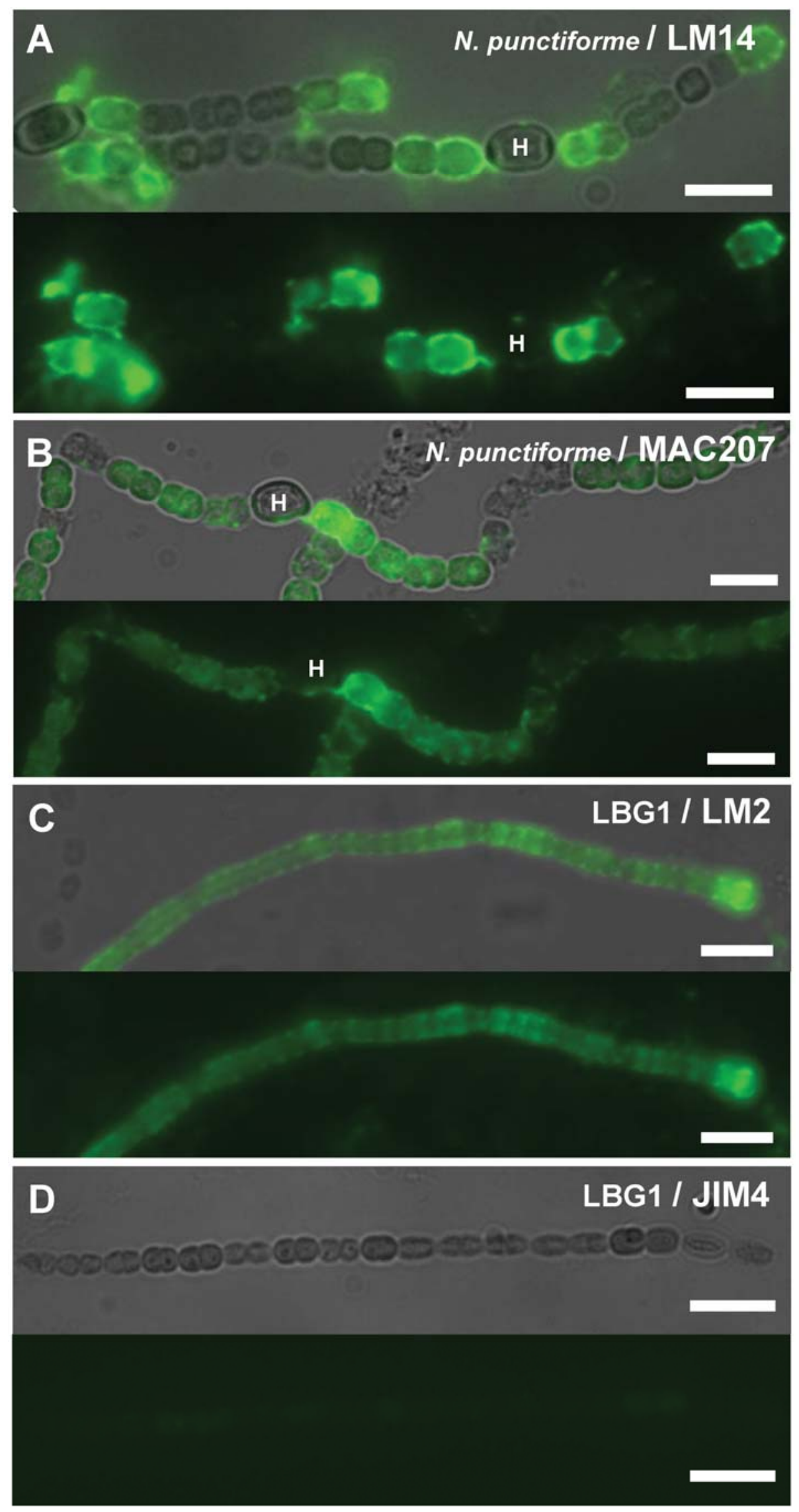

Fig. 2. A, Indirect immunofluorescence detection of arabinogalactan protein (AGP) glycan epitopes LM14 B, MAC207, and C, LM2 at the surface of freeliving but symbiotically competent cyanobacterial species. Paired images of fluorescein isothiocyanate (FITC) immunofluorescence and bright field (upper) with immunofluorescence alone (lower). LM14 and MAC207 are detected at the surface of Nostoc punctiforme and LM2 at the surface of Nostoc LBG1 filaments. D, Nonbinding antibody JIM4 is shown as a negative control. $\mathrm{H}=$ heterocyst. Scale bars $=10 \mu \mathrm{m}$. 
cleavage site may be vital, because cleavage at the former site generates a peptide with one $[\mathrm{AST}]-\mathrm{P}-\mathrm{X}_{(0,10)}-[\mathrm{AST}]-\mathrm{P}$ repeat (composed of an APAP sequence) and one TP repeat, whereas cleavage at the latter site results in a peptide with one AP and one TP repeat. Hence, depending on which cleavage site is found in the protein in vivo, this may or may not be a true AG peptide candidate.

\section{The LM14, MAC207, and LM2 AGP glycan epitopes are detected in gland mucilage and at the cyanobacterial-plant interface in the Gunnera-Nostoc symbiosis.}

Immunofluorescence analysis of thick sections of outer gland regions of uninfected Gunnera manicata with covering mucilage indicated the presence of the LM14, MAC207, and LM2 AGP epitopes. Micrographs for LM14 and LM2 are shown in Figure 5A and B. Sections of naturally infected stem glands in regions of intracellular symbionts also indicated the presence of the same three epitopes. The LM14 epitope was detected in the plant cell walls surrounding the symbiotic colonies and also at the surface of the symbiotic colonies themselves (Fig. 5C). This was also the case for MAC207 (not shown). By contrast, the LM2 epitope had a different profile of occurrence, being abundantly detected in the symbiotic colonies of Nostoc spp. within the G. manicata gland but was not detected in the plant cell walls adjacent to the symbiotic colonies (Fig. 5D).

The LM2 AGP glycan epitope is temporally regulated during the formation of the Nostoc-Blasia symbiosis.

The Nostoc-Blasia symbiosis can be readily established in uninfected plants (Adams and Duggan 2011). A 72-h timecourse experiment was carried out to assess the expression of AGP epitopes during the establishment of the Blasia-Nostoc symbiosis. LM14, MAC207, and LM2 were used to probe the $B$. pusilla symbiosis during the infection process. The auricles of uninfected B. pusilla and B. pusilla and Nostoc cells did not show any binding of LM14 or MAC207 antibodies throughout an infection time course of $72 \mathrm{~h}$ (data not shown). However, the LM2 AGP glycan epitope was specifically detected in auricle structures when $B$. pusilla was grown in sterile culture, prior to contact with cyanobacterial filaments, whereas no epitope was detected in nonsymbiotic thallus material (Fig. 6A, $0 \mathrm{~h}$, marked with a "T"). As the infection time course proceeded, the auricles began to lose their reactivity with the LM2 antibody. By $48 \mathrm{~h}$, hormogonia had started to invade the symbiotic space between the auricle wall and the inner papilla, encircling the inner papilla itself (Fig. 6B; hormogonia may be seen by red autofluorescence). The LM2 epitope remained detectable on the outer papillae but not on the inner. After $60 \mathrm{~h}$, many more cyanobacterial cells were present in the auricles and the LM2 epitope was no longer detected on the papillae (Fig. 6C). After $72 \mathrm{~h}$, the auricles were tightly packed with cyanobacterial cells. The ends of some filaments could be seen protruding from the auricle, and these reacted strongly with LM2 (Fig. 6D). As with the 60-h time point, the LM2 epitope was not detected on either the inner or outer papillae.

\section{DISCUSSION}

Putative AGP are present in free-living cyanobacteria.

Preliminary work had indicated that some anti-AGP antibodies may bind to concentrated Nostoc growth media (Snogerup 1997). The results presented here using ELISA, immunoblotting, and immunofluorescence procedures demonstrate that symbiotically competent Nostoc spp. express a range of carbohydrate epitopes thought previously to be exclusive to plant AGP. The epitopes of monoclonal antibodies LM14,
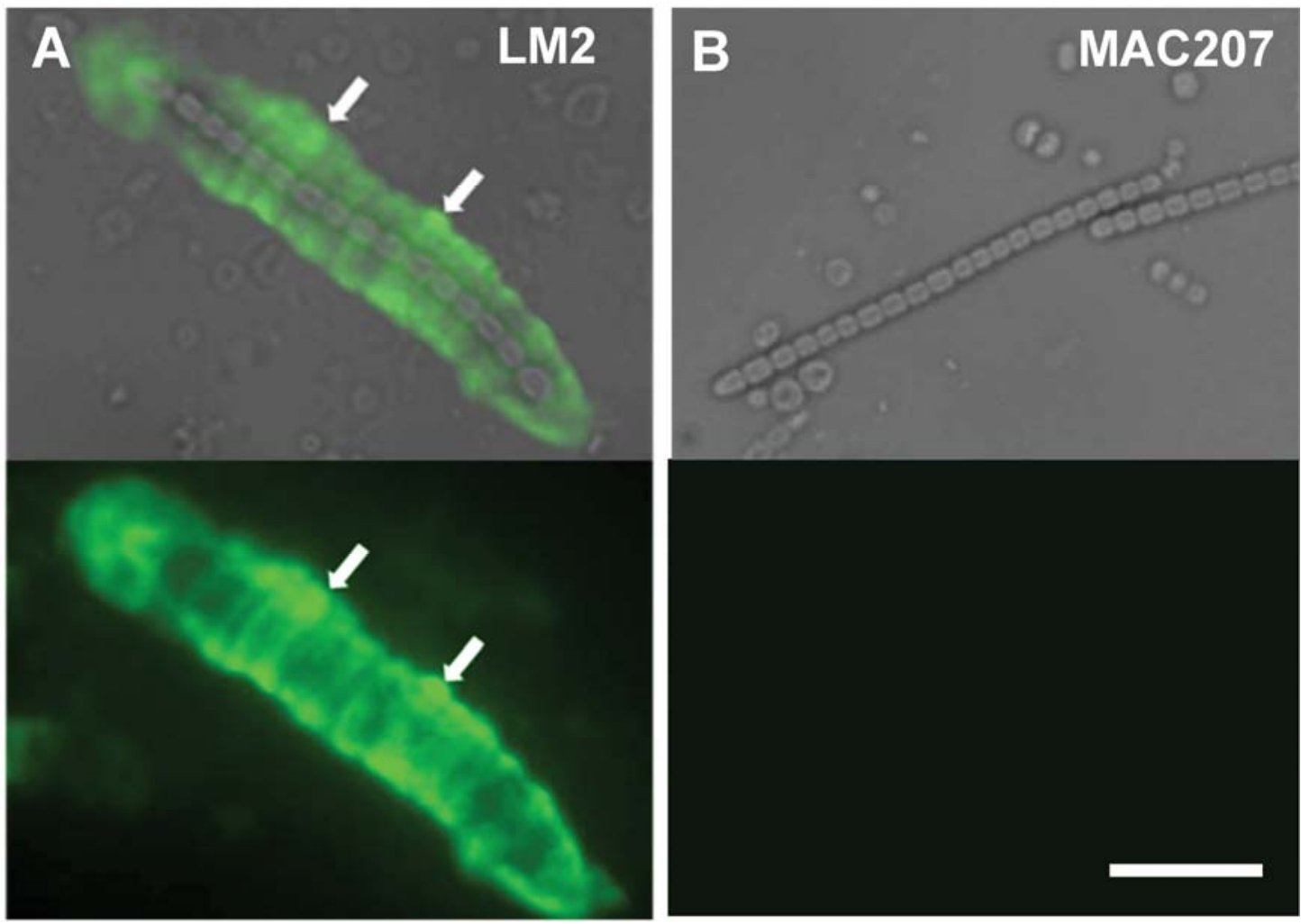

Fig. 3. A, Indirect immunofluorescence detection of the LM2 epitope at the surface of Nostoc LBG1 hormogonia. B, In this case, MAC207 does not bind. Cultures were $50 \mathrm{~h}$ postinduction. Paired images of immunofluorescence and bright field (upper) and immunofluorescence only (lower). Arrows indicate the edge of the mucilage sheath detected by the LM2 antibody. Scale bar $=20 \mu \mathrm{m}$. 
MAC207, and LM2 all contain glucuronic acid (Moller et al. 2008; Smallwood et al. 1996; Yates et al. 1996; unpublished observation) that is known to decorate core AG structures. The similarity in the binding profiles of LM14 and MAC207 in the diverse assays may indicate that they recognize structurally related epitopes. These observations suggest that AGP may be present in long-term laboratory-cultured, free-living Nostoc strains, such as N. punctiforme and Nostoc LBG1, which were originally isolated from plant symbioses but have been cultured away from plants for more than 20 years.

The occurrence of the AGP glycan epitopes, as detected by immunofluorescence, at the surface of cyanobacterial filaments was not uniform and the LM14 or MAC207 epitopes were generally most abundant at the surface of cells adjacent to heterocysts but appeared to be absent from the heterocysts them- selves (Fig. 2). Heterocyst cell walls are thicker and more complex than those of vegetative cells, having a polysaccharide layer, a glycolipid layer, and an outer fibrous layer external to the normal cell envelope (Adams and Duggan 1999). How the pattern of AGP glycan epitope occurrence relates to the filament cell heterogeneity or vegetative cell or heterocyst function is not clear at this stage.

Although previous studies of AGP core proteins have shown them to be highly variable in sequence and secondary structure (Faik et al. 2006; Schultz et al. 2000, 2002), we present further evidence that Nostoc cultures may express AGP by the identification of five putative AGP core proteins in the $N$. punctiforme translated proteome. All five putative core proteins possess regions strongly resembling $\mathrm{AG}$ glycomodules, and all are secreted proteins, as would be expected for AGP.

\section{NPUN_F0888 (233 aa)}

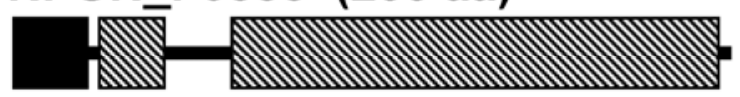

\section{NPUN_R0902 (482 aa)}

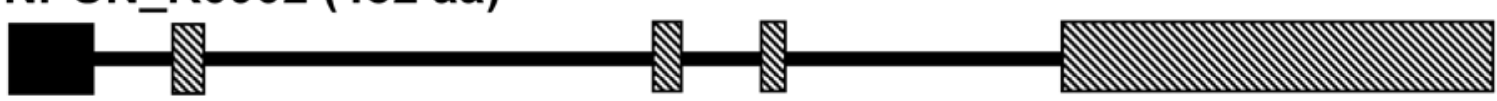

\section{NPUN_F4498 (63 aa)

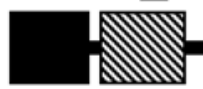

NPUN_R4210 (563 aa)

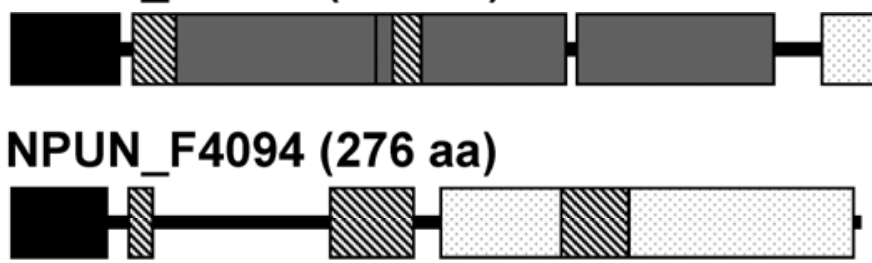

\section{Signal peptide Glycomodule-rich ([AST]-P) regions $\square$ S-layer homology regions Fasciclin domain}

Fig. 4. Schematic diagram to show candidate arabinogalactan proteins encoded in the Nostoc punctiforme genome. Included with the Nostoc database numbers is the complete protein length in amino acids. Lengths are relatively scaled. Putative protein domains are indicated.

Table 1. Summary of glycomodule motifs in putative arabinogalactan proteins (AGP) of Nostoc punctiforme

\begin{tabular}{|c|c|c|c|c|c|c|}
\hline \multirow[b]{2}{*}{ Gene locus (GenBank) } & \multirow[b]{2}{*}{ Protein description } & \multirow[b]{2}{*}{ Protein $(\mathbf{a a})^{\mathbf{b}}$} & \multicolumn{4}{|c|}{ Number of glycomodule motifs ${ }^{\mathrm{a}}$} \\
\hline & & & [AST]-P & $\left([\right.$ AST $]-P-X_{(0,10)}-[$ AST]-P) & [AST]-P-P & [AST]-P-P-P \\
\hline \multicolumn{7}{|l|}{ Classical AGP } \\
\hline NPUN F0888 & Putative uncharacterized protein & 233 & 3 & 15 & 4 & 0 \\
\hline NPUN_R0902 & Putative uncharacterized protein & 482 & 2 & 14 & 0 & 0 \\
\hline \multicolumn{7}{|l|}{ AG-peptides } \\
\hline NPUN_F4498 & Putative uncharacterized protein & 63 & $1(2)^{\mathrm{c}}$ & $1(0)^{\mathrm{c}}$ & 0 & 0 \\
\hline \multicolumn{7}{|l|}{ Fasciclin-linked AGP } \\
\hline NPUN_R4210 & $\beta-\mathrm{Ig}-\mathrm{H} 3 / \mathrm{fasciclin}$ & 563 & 3 & 2 & 0 & 0 \\
\hline NPUN_F4094 & $\beta$-Ig-H3/fasciclin & 276 & 3 & 1 & 1 & 0 \\
\hline
\end{tabular}



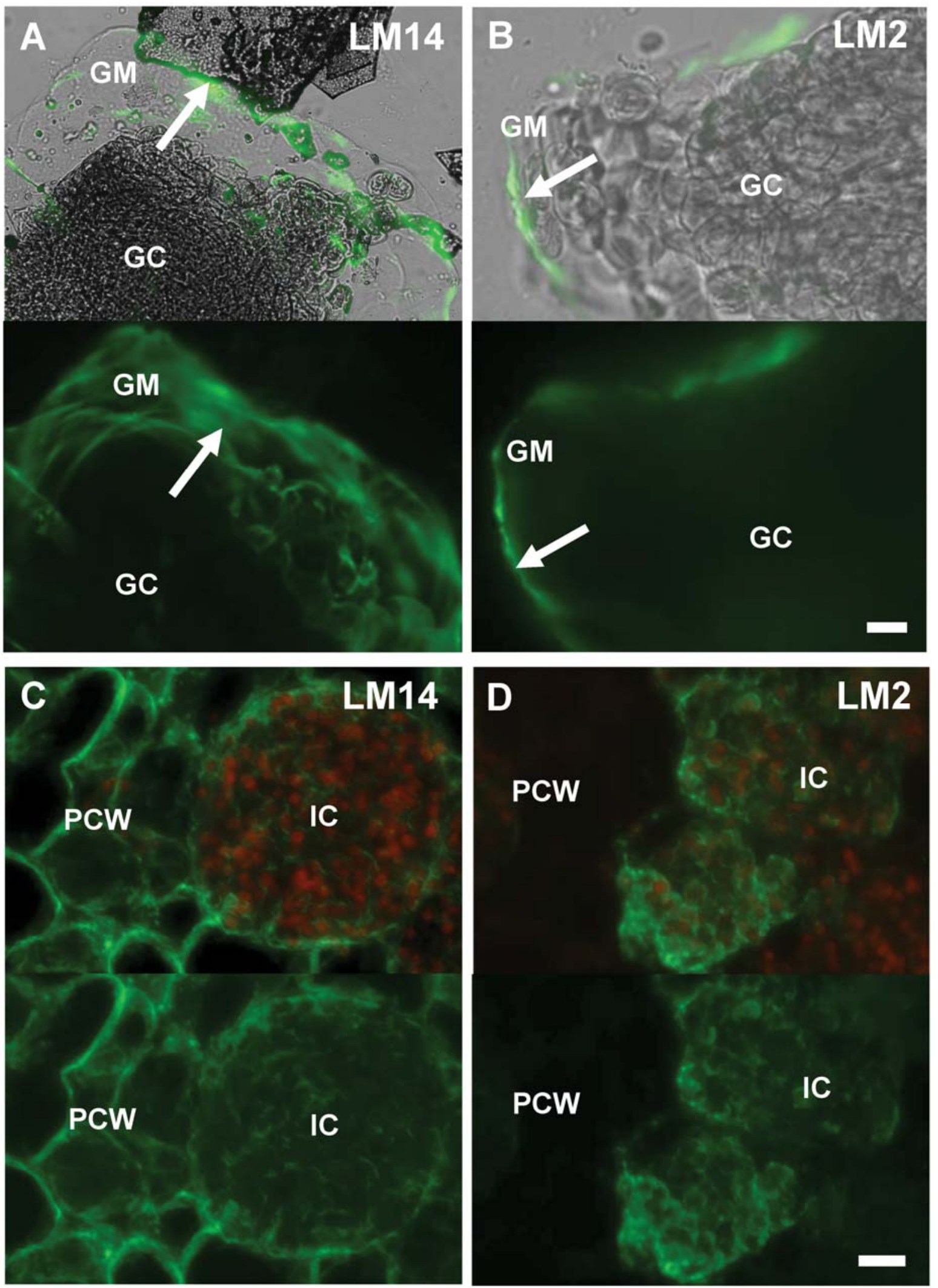

Fig. 5. Indirect immunofluorescence detection of arabinogalactan protein (AGP) epitopes in Gunnera manicata stem glands at the symbiotic surface of Nostoc-Gunnera symbioses. Paired images of fluorescein isothiocyanate (FITC) immunofluorescence and bright field (upper) with immunofluorescence alone (lower) are presented for uninfected gland surfaces with mucilage are shown for A, LM14 and B, LM2. Paired images of FITC immunofluorescence and red autofluorescence indicating presence of cyanobacteria (upper) with immunofluorescence alone (lower) are shown for sections through regions with intracellular symbionts for C, LM14 and D, LM2. Arrows indicate AGP detection in mucilage at gland surfaces. GM = gland mucilage, GC = gland cells, and PCW = plant cell walls adjacent to cells with intracellular symbionts (ICs). Scale bars $=20 \mu \mathrm{m}$. 
Post-translational glycosylation of AGP peptide cores is required to generate the large-branched glycan structure of AGP but evidence of glycosylation in cyanobacteria is somewhat sparse. SwmA, a protein implicated in motility in Synechococcus sp. (a nonflagellated marine cyanobacterial species), has been shown to be glycosylated and to contain N-glycosylation sites (Brahamsha 1996). Oscillin is another motility-associated protein found on the cell surface and which has a glycosylated structure, containing xylose, glucose, rhamnose, fucose, arabinose, and galactose (Hoiczyk and Baumeister 1997). More recently, a glycoprotein has been identified in the toxic cyanobacterium Microcystis aeruginosa (Zilliges et al. 2008). This protein is implicated in cell-to-cell contact and is post-translationally modified by the addition of $O$-linked glycans. Hence, although little work has been done in the field, it appears that cyanobacteria possess the ability for post-translational glycosylation and these modified proteins are involved in cell surface processes.

Although we have demonstrated the occurrence of AGP glycan epitopes and identified putative AGP core protein sequences, we have not made a link between expressed (glyco)proteins and the specific epitopes. This is a challenging area, and links between glycan epitopes and specific AGP core protein sequences are not yet easy to establish for plant AGP (Ellis et al. 2010; Seifert and Roberts 2007).

\section{AGP epitopes at symbiotic interfaces.}

The role of putative AGP at the surface of free-living cyanobacteria grown for thousands of generations in laboratory con- ditions is unknown. However, the observation that the same set of three AGP epitopes is detected in the mucilage of G. manicata glands raises the possibility that they may play a role in the initiation or maintenance of symbioses-although this remains to be demonstrated. Gunnera gland mucilage has previously been implicated in the infection process (Rasmussen et al. 1994, 1996; Towata 1985). It is of interest that the LM14- or MAC207-reactive epitopes were also present in the surrounding cell walls but that the LM2-reactive epitope was specific to the symbiotic colonies within the gland structure, suggesting that the epitope may be produced by the symbiont.

NPUN_R4210, identified in this study as a putative FLA, is upregulated in symbiotically associated Nostoc spp., suggesting that it has a role in the maintenance of a stable symbiosis (Ekman et al. 2006). Another fasciclin-containing protein, NPUN_F4094, also identified here as being a putative FLA, has been detected in a functional proteomics study as a protein involved in cell motility, secretion, or cell envelope biogenesis (Ran et al. 2007). Fasciclin domain proteins have previously been implicated in cyanobacterial symbioses (Ekman et al. 2006; Paulsrud and Lindblad 2002).

AGP have previously been shown to be present in the cell walls of liverworts, although those tested do not host cyanobionts (Basile and Basile 1987). In axenic (uninfected) Blasia cultures, the LM2 AGP glycan epitope was specifically detected on the inner wall of the auricle as well as the inner and outer papillae but not in the surrounding nonsymbiotic thallus cells (Fig. 6, $0 \mathrm{~h}$ ). As the auricle became populated with cyanobacterial hormogonia (also expressing the LM2 epitope),
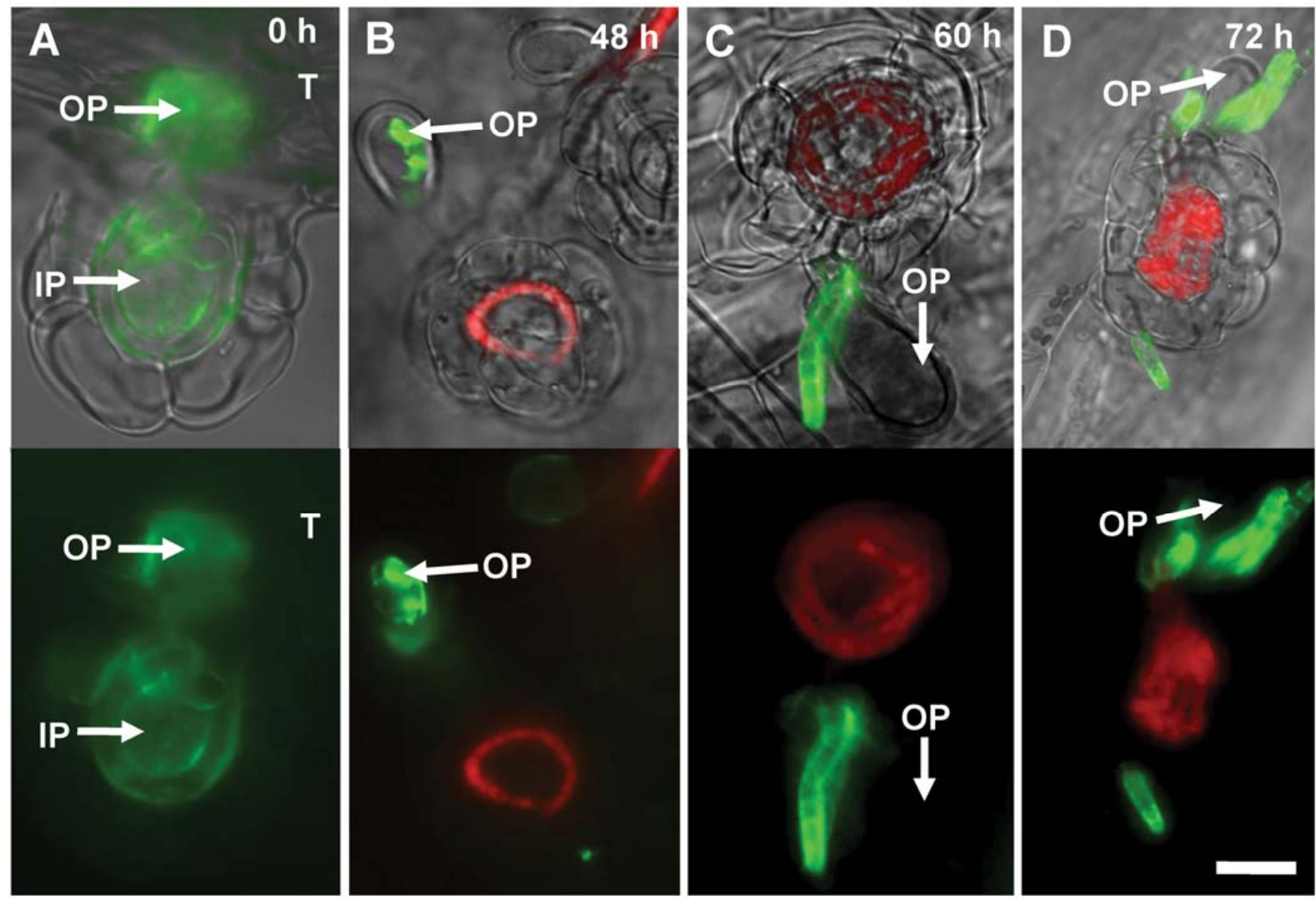

Fig. 6. Indirect immunofluorescence detection of the LM2 arabinogalactan protein (AGP) epitope in Blasia symbiotic structures (auricles) through a 72-h infection time course. Paired images of (top) bright field, cyanobacterial autofluorescence (red), and immunofluorescence (green) with (bottom) autofluorescence/immunofluorescence only for $\mathbf{A}, 0 \mathrm{~h} ; \mathbf{B}, 48 \mathrm{~h} ; \mathbf{C}, 60 \mathrm{~h}$; and $\mathbf{D}, 72 \mathrm{~h}$. Inner and outer papillae(IP and OP, respectively) are indicated along with nonsymbiotic thallus material $(\mathrm{T})$. Scale $\mathrm{bar}=20 \mu \mathrm{m}$. 
LM2 epitope detection on both inner and outer papillae was reduced. By $60 \mathrm{~h}$, the LM2 epitope was no longer detected on the outer papilla but abundant on adjacent hormogonia (Fig. 6, 60 and $70 \mathrm{~h}$ ). In the case of the outer papillae, this seems to be due to loss of the epitope, because these papillae always remain accessible to the antibody but show significant reduction in LM2 binding (Fig. 6, 60 and $72 \mathrm{~h}$ ). However, as the cyanobacteria completely fill the interior of the auricle, the lack of LM2 epitope detection at the interior auricle wall and inner papillae may be due to restricted access. This appears to be supported by analysis at 60 and $72 \mathrm{~h}$, where the ends of cyanobacterial filaments protruding from the auricle are bound by the antibody, whereas those parts of the filament within the auricle are not. Signaling and attraction between hormogonia and the auricle structure is known to occur (Nilsson et al. 2006).

Gunnera stem gland mucilage is known to contain high levels of sugars such as arabinose (Khamar et al. 2010), a possible hormogonia attractant which may be released from polymers such as AGP by the extracellular enzyme arabinofuranosidase, the expression level of which is elevated in G. manicata stem tissue containing glands compared with that lacking glands (Khamar et al. 2010). There are parallels between Gunnera gland development with adventitious root formation, and it has been suggested that glands may be modified adventitious roots (Chiu et al. 2005). Plant AGP have been extensively implicated in root generation and growth (Knox et al. 1991; Seifert and Roberts 2007; van Hengel and Roberts 2003).

\section{Did plant AGP originate in cyanobacteria?}

Evidence is growing that a large amount of genetic information in plants originated from the cyanobacterial ancestors of plastids, which first appeared 1.2 billion years ago when a cyanobacterium invaded a biciliate protozoan (Cavalier-Smith 2000; Deusch et al. 2008). A study of gene acquisition from cyanobacteria in four eukaryotes has estimated that $14 \%$ of plant proteins are of cyanobacterial origin and that, of all cyanobacterial genomes, that of the genus Nostoc is the closest to that of plants (Deusch et al. 2008). This analysis implies that the ancestor of plastids was an organism similar to filamentous, heterocyst-forming cyanobacteria typified by Nostoc spp. (Deusch et al. 2008). Therefore, it is possible that AGP proteoglycans may represent a class of glycosylated proteins that originally evolved in cyanobacteria, and that have been transferred to a plant host at some point in the last 500 million years. It has also been speculated that the capacity for cellulose synthesis is cyanobacterial in origin (Nobles and Brown 2004; Nobles et al. 2001). It is of interest in this regard that AGP are implicated in several aspects of cell wall function in plants (Ellis et al. 2010; Seifert and Roberts 2007) and it is possible that several aspects of plant cell wall structure and assembly originated in cyanobacteria.

In summary, we present evidence that free-living cyanobacteria of the genus Nostoc produce AGP glycan epitopes and contain sequences of putative AGP core proteins. The same specific glycan epitopes are present in the symbiotic structures of both G. manicata and B. pusilla. Although we are, at present, unable to show a direct relationship between the specific AGP glycan epitopes identified by immunochemistry and the predicted AGP core proteins, we suggest that, taken together, the results imply that Nostoc spp. can express AGP-like proteins, previously thought exclusive to the plant kingdom.

\section{MATERIALS AND METHODS}

\section{Culture of cyanobacterial strains.}

N. punctiforme ATCC 29133 and Nostoc LBG1 (a symbiotic strain isolated from a hornwort) were grown using variations of liquid BG11 medium (Rippka et al. 1979), either with $(+\mathrm{N})$ or without $(-\mathrm{N})$ added sodium nitrate $(17 \mathrm{mM})$. In addition to these standard nutrients, glucose was included in Nostoc LBG1 $-\mathrm{N}$ cultures at a final concentration of $35 \mathrm{mM}$ to suppress the natural tendency of this cyanobacterium to transform into hormogonia when grown in nitrogen-fixing culture. All cultures were incubated at $100 \mathrm{rpm}$ at $30^{\circ} \mathrm{C}$ under continuous light of $100 \mu \mathrm{mol}$ photons $\mathrm{m}^{-2} \mathrm{~s}^{-1}$ photosynthetically active radiation (PAR). To generate hormogonia, a stable culture of Nostoc LBG1 grown in BG11-N supplemented with $35 \mathrm{mM}$ glucose (as described above) was centrifuged $(3,500 \times g, 2 \mathrm{~min})$ and washed twice with BG11-N before being transferred to BG11-N with no added glucose. This culture was incubated overnight under standard conditions (described above) and hormogonia differentiation was checked by microscopy to confirm that the proportion of hormogonia to vegetative filaments was $>90 \%$.

\section{Plant materials.}

Samples of naturally infected G. manicata 'Linden' glands were dissected from plants grown at Harewood House Estate, West Yorkshire, United Kingdom. Uninfected samples of the liverwort B. pusilla L. were obtained from Paula Duggan (University of Leeds) and aseptically subcultured into BG11+N media in conical flasks every month. These were kept at $22^{\circ} \mathrm{C}$ on an orbital shaker (100 rpm) under artificial light at 100 $\mu \mathrm{mol}$ photons $\mathrm{m}^{-2} \mathrm{~s}^{-1}$ PAR and a cycle of $12 \mathrm{~h}$ of light and $12 \mathrm{~h}$ of darkness.

\section{AGP-directed monoclonal antibodies.}

The eight rat anti-AGP monoclonal antibodies used in this study were MAC207 (Pennell et al. 1989), JIM4 (Knox et al. 1989), JIM13, JIM14, JIM15, JIM16 (Knox et al. 1991), LM2 (Smallwood et al. 1996), and LM14 (Moller et al. 2008). LM15, an anti-xyloglucan monoclonal antibody, was used as a negative control for ELISA (Marcus et al. 2008). In all cases, the antibodies were used as unpurified hybridoma cell culture supernatants.

\section{ELISA analysis of AGP in cyanobacterial cell material.}

The chlorophyll a (chl a) content of cyanobacterial cultures was determined by a methanol extraction assay and the absorbance read at $665 \mathrm{~nm}$ (Tandeau de Marsac and Houmard 1988; although the extinction coefficient used was modified to 12.9447 as described by Ritchie 2006). Cultures were then diluted to a chl a value of $1 \mu \mathrm{g} / \mathrm{ml}$ to standardize loading for the immunoassay and used to coat the ELISA microtiter plate (Immuno 96 MicroWell plates; NUNC, Langenselbold, Germany) overnight at $4^{\circ} \mathrm{C}$. The plates were dried and stored at $-20^{\circ} \mathrm{C}$ before use. ELISA plates were blocked with $3 \%$ (wt/ vol) milk protein in phosphate-buffered saline (MP/PBS) overnight, $200 \mu \mathrm{l}$ per well, before washing nine times in tap water. Primary rat antibodies diluted 10 -fold in $3 \%$ MP/PBS were added and incubated for $1 \mathrm{~h}$ at room temperature, before washing (nine times in tap water). Plates were then incubated with a 1,000-fold dilution of secondary antibody (anti-rat immunoglobulin $\mathrm{G}$ [IgG] [whole molecule] coupled to horseradish peroxidase [HRP]) (Sigma-Aldrich, Gillingham, U.K.) in MP/ PBS for $1 \mathrm{~h}$ at room temperature, before being washed (nine times in tap water). The HRP substrate $\left(18 \mathrm{ml}\right.$ of $\mathrm{H}_{2} \mathrm{O}, 2 \mathrm{ml}$ of $1 \mathrm{M}$ sodium acetate buffer [pH 6.0], $200 \mu \mathrm{l}$ of 3,3,5'5'-tetramethyl benzidine [Sigma T-2885, $10 \mathrm{mg} / \mathrm{ml}$ in dimethyl sulfoxide], and $20 \mu \mathrm{l}$ of $6 \%$ [vol/vol] $\mathrm{H}_{2} \mathrm{O}_{2}$ ) was then added and allowed to develop for $5 \mathrm{~min}$ before $2.5 \mathrm{M}$ sulfuric acid (30 $\mu \mathrm{l} /$ well) was added to stop the reaction. Absorbance values were read at $450 \mathrm{~nm}$ using a Bio-tek Instruments ELX800 automated universal microplate reader. Rat antibody LM15 was used as a negative control for these analyses and absorbance 
values for the nonspecific binding of this antibody were subtracted from the values determined with anti-AGP antibodies.

\section{Immunoblotting of growth media.}

Growth medium $(50 \mathrm{ml})$ was taken from 10-day-old cultures of $N$. punctiforme and Nostoc LBG1 and filtered through a $0.45-\mu \mathrm{m}$ filter to remove cells. These media were then freeze dried and resuspended in sterile distilled water to a 10- to 20fold increased concentration. Samples were then separated using standard SDS polyacrylamide gel electrophoreses with $30 \mu \mathrm{l}$ added per lane. An 8- to $220-\mathrm{kDa}$ molecular weight marker set (ColorBurst; Sigma-Aldrich) was included on each gel. The resulting blots were then blocked overnight $\left(4^{\circ} \mathrm{C}\right)$ in $3 \% \mathrm{MP} / \mathrm{PBS}$. The blots were then washed thoroughly with water and rat monoclonal antibodies LM14, MAC207, and LM2 were diluted 10-fold in 3\% MP/PBS for $1 \mathrm{~h}$ at room temperature. After 5-min washes three time with PBS, the blots were incubated with the secondary antibody (anti-rat IgG coupled to HRP [Sigma-Aldrich] diluted 1,000-fold in 3\% MP/PBS for $1.5 \mathrm{~h}$ at room temperature) and the PBS washing steps were repeated. The blots were then developed using HRP color substrate $\left(25 \mathrm{ml}\right.$ of $\mathrm{H}_{2} \mathrm{O}, 5 \mathrm{ml}$ of $\mathrm{MeOH}$ containing $10 \mathrm{mg} / \mathrm{ml}$ 4-chloro-1-napthol, and $30 \mu \mathrm{l}$ of $6 \%$ [vol/vol] $\mathrm{H}_{2} \mathrm{O}_{2}$ ) before being washed in water.

\section{Immunofluorescence microscopy.}

Cyanobacterial cells were fixed $\mathrm{O} / \mathrm{N}$ in a $4 \%$ (wt/vol) formaldehyde (as for plant material, discussed below), aliquotted onto Vectabond-coated multiwell slides (Vector Laboratories, Peterborough, U.K.) and allowed to dry at $37^{\circ} \mathrm{C}$ for $1 \mathrm{~h}$ before being blocked for $30 \mathrm{~min}$ with $5 \% \mathrm{MP} / \mathrm{PBS}$. Wells were then incubated with primary rat antibodies diluted 10-fold in 5\% MP/PBS for $1 \mathrm{~h}$ at room temperature. A negative control well was incubated with 5\% MP/PBS only. After washing with PBS (three times, $5 \mathrm{~min}$ ), slides were incubated with the secondary antibody, anti-rat IgG coupled to fluorescein isothiocyanate (Sigma) diluted 100-fold in 5\% MP/PBS for $1.5 \mathrm{~h}$ at room temperature in darkness. After washing ( $5 \mathrm{~min}$, three times, with PBS), slides were mounted using Citifluor AF2 antifade reagent (glycerol suspension; Agar Scientific Stansted, U.K.). Excised samples of environmentally infected G. manicata glands (from Harewood House Estate, West Yorkshire, U.K.) were fixed, wax-embedded, and sectioned to a thickness of $10 \mu \mathrm{m}$ as described (Marcus et al. 2008). Sections were analyzed by indirect immunofluorescence with anti-AGP monoclonal antibodies using the same protocol as described for cyanobacterial samples above. All samples were examined using an Olympus BX-61 microscope with epifluorescence irradiation. Images were captured using a Hamamatsu ORCA285 camera and Volocity software.

\section{Bioinformatics.}

The $N$. punctiforme proteome was obtained from the SwissProt/TrEMBL ExPASy proteomics server. Prior studies were used to identify characteristic sequences (Faik et al. 2006; Schultz et al. 2000, 2002).

Classical AGP. Proteins rich in PAST in the Nostoc proteome were identified using the PERL script as described (Schultz et al. 2002), set to isolate only those proteins with $>50 \%$ PAST. Resulting proteins were then analyzed using SignalP (Bendtsen et al. 2004) to identify those with secretion signals and the location of secretion signal cleavage sites, and InterProScan (Zdobnov and Apweiler 2001) to identify any conserved domains. Sequences with secretion signals were further analyzed by eye using the Jalview program (Waterhouse et al. 2009 ) to identify potential AG glycomodules.

$A G$ peptides. Using the PERL script (Schultz et al. 2002), all proteins shorter than 75 residues were identified, and then ana- lyzed to isolate those possessing $>35 \%$ PAST. These were then analyzed as for classical AGP (discussed above).

FLA. All cyanobacterial fasciclin-containing proteins were identified from the InterPro IPR000782 FAS1 domain family. A consensus sequence was then generated using the MUSCLE multiple sequence alignment system (Edgar 2004a and b) and Jalview (Waterhouse et al. 2009). This sequence then identified proteins containing fasciclin domains in the $N$. punctiforme proteome using BLASTp $(E=0.001$, BLOSUM62 matrix) (Altschul et al. 1997). These proteins were then analyzed using the PERL script (Schultz et al. 2002) to isolate those containing $>35 \%$ PAST. These sequences were then analyzed as for classical AGP (see above).

\section{ACKNOWLEDGMENTS}

We thank Dr. R. Jackson and J. Fuller (University of Leeds) for methodological and technical guidance and assistance with the bioinformatics techniques used in this article; S. Marcus for provision of technical knowledge and assistance as well as the monoclonal antibodies; the Harewood House Estate, Leeds for the kind donation of G. manicata plants; the Elhai (Virginia Commonwealth University) and Bergman (University of Stockholm) research groups, particularly J. Klint and W.-L. Chiu, for their kind and insightful communications; and an anonymous referee for extensive and helpful comments on a previous version of this manuscript. This work was funded by a UK Biotechnology and Biological Sciences Research Council studentship awarded to O. Jackson.

\section{LITERATURE CITED}

Adams, D. G. 2002. Cyanobacteria in symbiosis with hornworts and liverworts. Pages 117-135 in: Cyanobacteria in Symbiosis. A. N. Rai, B. Bergman, and U. Rasmussen, eds. Kluwer Academic Publishers, Dordrecht, The Netherlands.

Adams, D. G., and Duggan, P. S. 1999. Heterocyst and akinete differentiation in cyanobacteria. New Phytol. 144:3-33.

Adams, D.G., and Duggan, P. S. 2008. Cyanobacteria-bryophyte symbioses. J. Exp. Bot. 59:1047-1058.

Adams, D. G., and Duggan, P. S. 2011. Signalling in cyanobacteria-plant symbioses. Pages 93-122 in: Signalling and Communication in Plant Symbiosis. S. Perotto and F. Baluška, eds. Springer, Berlin.

Altschul, S. F., Madden, T. L., Schäffer, A. A., Zhang, J., Zhang, Z., Miller, W., and Lipman, D. J. 1997. Gapped BLAST and PSI-BLAST: A new generation of protein database search programs. Nucleic Acids Res. 25:3389-3402.

Basile, D. V., and Basile, M. R. 1987. The occurrence of cell wall-associated arabinogalactan proteins in the Hepaticae. Bryologist 90:401404.

Bendtsen, J. D., Nielsen, H., von Heijne, G., and Brunak, S. 2004. Improved prediction of signal peptides: SignalP 3.0. J. Mol. Biol. 340:783-795.

Bergman, B. 2002. The Nostoc-Gunnera symbiosis. Pages 207-232 in Cyanobacteria in Symbiosis. A. N. Rai, B. Bergman, and U. Rasmussen, eds. Kluwer Academic Publishers, Dordrecht, The Netherlands.

Bergman, B., Ran, L. and Adams, D. G. 2008. Cyanobacterial-plant symbioses: Signalling and development. Pages 447-473 in: The Cyanobacteria: Molecular Biology, Genomics and Evolution. A. Herrero and E. Flores, eds. Caister Academic Press. Wymondham, U.K.

Berry, A. M., Rasmussen, U., Bateman, K., Huss-Danell, K., Lindwall, S., and Bergman, B. 2002. Arabinogalactan proteins are expressed at the symbiotic interface in root nodules of Alnus spp. New Phytol. 155:469479.

Black, K. G., Parsons, R., and Osborne, B. A. 2002. Uptake and metabolism of glucose in the Nostoc-Gunnera symbiosis. New Phytol. 153:297-305.

Bonnett, H. T., and Silvester, W. B. 1981. Specificity in the GunneraNostoc endosymbiosis. New Phytol. 89:121-128.

Brahamsha, B. 1996. An abundant cell-surface polypeptide is required for swimming by the nonflagellated marine cyanobacterium Synechococcus. Proc. Natl. Acad. Sci. U.S.A. 93:6504-6509.

Cavalier-Smith, T. 2000. Membrane heredity and early chloroplast evolution. Trends Plant Sci. 5:174-182.

Chatterjee, S., and Mayor, S. 2001. The GPI-anchor and protein sorting. Cell. Mol. Life Sci. 58:1969-1987.

Chiu, W.-L., Peters, G. A., Levieille, G., Still, P. C., Cousins, S., Osborne, B., and Elhai J. 2005. Nitrogen deprivation stimulates symbiotic gland development in Gunnera manicata. Plant Physiol. 139:224-230.

Chungjatupornchai, W., and Fa-aroonsawat, S. 2009. Translocation of 
green fluorescent protein to cyanobacterial periplasm using ice nucleation protein. J. Microbiol. 47:187-192.

Costa, J.-L., and Lindblad, P. 2002. Cyanobacteria in symbiosis with cycads. Pages 195-205 in: Cyanobacteria in Symbiosis. A. N. Rai, B. Bergman, and U. Rasmussen, eds. Kluwer Academic Publishers, Dordrecht, The Netherlands.

Crick, D. C., Mahapatra, S., and Brennan, P. J. 2001. Biosynthesis of the arabinogalactan-peptidoglycan complex of Mycobacterium tuberculosis. Glycobiology 11:107R-118R

Deusch, O., Landan, G., Roettger M., Gruenheit, N., Kowallik, K. V., Allen, J. F., Martin, W., and Dagan, T. 2008. Genes of cyanobacterial origin in plant nuclear genomes point to a heterocyst-forming plastid ancestor. Mol. Biol. Evol. 25:748761.

Edgar, R. C. 2004a. MUSCLE: Multiple sequence alignment with high accuracy and high throughput. Nucleic Acids Res. 32:1792-1797.

Edgar, R. C. 2004b. MUSCLE: A multiple sequence alignment method with reduced time and space complexity. BMC Bioinf. 5:113.

Ekman, M., Tollbäck, P., Klint, J., and Bergman, B. 2006. Protein expression profiles in an endosymbiotic cyanobacterium revealed by a proteomic approach. Mol. Plant-Microbe Interact. 19:1251-1261.

Ellis, M., Egelund, J., Schultz, C. J., and Bacic, A. 2010. Arabinogalactanproteins (AGPs): Key regulators at the cell surface? Plant Physiol. 153:403-419.

Faik, A., Abouzouhair, J., and Sarhan, F. 2006. Putative fasciclin-like arabinogalactan-proteins (FLA) in wheat (Triticum aestivum) and rice (Oryza sativa): Identification and bioinformatic analyses. Mol. Genet. Genomics 276:478-494.

Flores, E., and Herrero, A. 2010. Compartmentalised function through cell differentiation in filamentous cyanobacteria. Nat. Rev. Microbiol. 8:3950 .

Gaspar, Y., Johnson, K. L., McKenna, J. A., Bacic, A., and Schultz, C. J. 2001. The complex structures of arabinogalactan-proteins and the journey towards understanding function. Plant Mol. Biol. 47:161-176.

Hoiczyk, E., and Baumeister, W. 1997. Oscillin, an extracellular, $\mathrm{Ca}^{2+}$ binding glycoprotein essential for the gliding motility of cyanobacteria. Mol. Microbiol. 26:299-708.

Johansson, C., and Bergman, B. 1994. Reconstitution of the symbiosis of Gunnera manicata Linden-cyanobacterial specificity. New Phytol. 126:643-652.

Johnson, K. L., Jones, B. J., Bacic, A., and Schultz, C. J. 2003. The fasciclin-like arabinogalactan proteins of Arabidopsis. A multigene family of putative cell adhesion molecules. Plant Physiol. 133:1911-1925.

Khamar, H. J., Breathwaite, E. K., Prasse, C. E., Fraley, E. R., Secor, C. R., Chibane, F. L., Elhai, J., and Chiu, W.-L. 2010. Multiple roles of soluble sugars in the establishment of Gunnera-Nostoc endosymbisos. Plant Physiol. 154:1381-1389.

Kluge, M., Mollenhauer, D., Wolf, E., and Schüßler, A. 2002. The NostocGeosiphon endosymbiosis. Pages 19-30 in: Cyanobacteria in Symbiosis. A. N. Rai, B. Bergman, and U. Rasmussen, eds. Kluwer Academic Publishers, Dordrecht, The Netherlands.

Knox, J. P. 2008. Revealing the structural and functional diversity of plant cell walls. Curr. Opin. Plant Biol. 11:308-313.

Knox, J. P., Day, S., and Roberts, K. 1989. A set of cell surface glycoproteins forms an early position, but not cell type, in the root apical meristem of Daucus carota L. Development 106:47-56.

Knox, J. P., Linstead, P. J., Peart, J., Cooper, C., and Roberts, K. 1991. Developmentally-regulated epitopes of cell surface arabinogalactan-proteins and their relation to root tissue pattern formation. Plant J. 1:317326.

Lechno-Yossef, S., and Nierzwicki-Bauer, S. A. 2002. Azolla-Anabaena symbiosis. Pages 153-178 in: Cyanobacteria in Symbiosis. A. N. Rai, B. Bergman, and U. Rasmussen, eds. Kluwer Academic Publishers, Dordrecht, The Netherlands.

Lee, K. J. D., Sakata, Y., Mau, S.-L., Pettolino, F., Bacic, A., Quatrano, R. S., Knight, C. D., and Knox, J. P. 2005. Arabinogalactan proteins are required for apical cell extension in the moss Physcomitrella patens. Plant Cell 17:3051-3065.

Marcus, S. E., Verhertbruggen, Y., Hervé, C., Ordaz-Ortiz, J. J., Farkas, V., Pedersen, H. L., Willats, W. G. T., and Knox, J. P. 2008. Pectic homogalacturonan masks abundant sets of xyloglucan epitopes in plant cell walls. BMC Plant Biol. 8:60

Mesnage, S., Fontaine, T., Mignot, T., Delepierre, M., Mock, M., and Fouet, A. 2000. Bacterial SLH domain proteins are non-covalently anchored to the cell surface via a conserved mechanism involving wall polysaccharide pyruvylation. EMBO (Eur. Mol. Biol. Organ.) J. 19:4473-4484.

Moller, I., Marcus, S. E., Haeger, A., Verhertbruggen, Y., Verhoef, R., Schols, H., Mikklesen, J. D., Knox, J. P., and Willats, W. 2008. Highthroughput screening of monoclonal antibodies against plant cell wall glycans by hierarchical clustering of their carbohydrate microarray binding profiles. Glycocon. J. 25:37-48.

Nilsson, M., Rasmussen, U., and Bergman, B. 2006. Cyanobacterial chemotaxis to extracts of host and non-host plants. FEMS (Fed. Eur. Microbiol. Soc.) Microbiol. Ecol. 55:382-390.

Nobles, D. R., and Brown, R. M. 2004. The pivotal role of cyanobacteria in the evolution of cellulose synthases and cellulose synthase-like proteins. Cellulose 11:437-448.

Nobles, D. R., Romanovicz, D. K., and Brown, R. M. 2001. Cellulose in cyanobacteria. Origin of vascular plant cellulose synthase? Plant Physiol. 127:529-542.

Nothnagel, E. A. 1997. Proteoglycans and related components in plant cells. Int. Rev. Cytol. 174:195-291.

Osborne, B., Doris, F., Cullen, A., McDonald, R., Campbell, G., and Steer, M. 1991. Gunnera tinctoria: An unusual nitrogen-fixing invader-this water-loving species may offer insights into the development of terrestrial plants. Bioscience 41:224-234.

Paulsrud, P., and Lindblad, P. 2002. Fasciclin domain proteins are present in Nostoc symbionts of lichens. Appl. Environ. Microbiol. 68:20362039

Pennell, R. I., Knox, J. P., Scofield, G. N., Selvendran, R. R., and Roberts, K. 1989. A family of abundant plasma membrane-associated glycoproteins related to the arabinogalactan proteins is unique to flowering plants. J. Cell Biol. 108:1967-1977.

Pereira, S., Zille, A., Micheletti, E., Moradas-Ferreira, P., De Philippis, R., and Tamagnini, P. 2009. Complexity of cyanobacterial exopolysaccharides: Composition, structures, inducing factors and putative genes involved in their biosynthesis and assembly. FEMS (Fed. Eur. Microbiol. Soc.) Microbiol. Rev. 33:917-941.

Ran, L., Huang, F., Ekman, M., Klint, J., and Bergman, B. 2007. Proteomic analyses of the photoauto- and diazotrophically grown cyanobacterium Nostoc sp. PCC 73102. Microbiology 153:608-618.

Rasmussen, U., Johansson, C., and Bergman, B. 1994. Early communication in the Gunnera-Nostoc symbiosis: Plant-induced cell differentiation and protein synthesis in the cyanobacterium. Mol. Plant-Microbe Interact. 7:696-702.

Rasmussen, U., Johansson, C., Renglin, A., Petersson, C., and Bergman, B. 1996. A molecular characterization of the Gunnera-Nostoc symbiosis Comparison with Rhizobium- and Agrobacterium-plant interactions. New Phytol. 133:391-398.

Rikkinen, J. 2002. Cyanolichens: An evolutionary overview. Pages 31-72 in Cyanobacteria in Symbiosis. A. N. Rai, B. Bergman, and U. Rasmussen, eds. Kluwer Academic Publishers, Dordrecht, The Netherlands.

Rippka, R., Deruelles, J., Waterbury, J., Herdman, M., and Stanier, R. Y. 1979. Generic assignments, strain histories and properties of pure cultures of cyanobacteria. J. Gen. Microbiol. 111:1-61.

Ritchie, R. J. 2006. Consistent sets of spectrophotometric chlorophyll equations for acetone, methanol and ethanol solvents. Photosyn. Res. 89:27-41.

Schultz, C. J., and Harrison, M. J. 2008. Novel plant and fungal AGP-like proteins in the Medicago truncatula-Glomus intraradices arbuscular mycorrhizal symbiosis. Mycorrhiza 18:403-412.

Schultz, C. J., Johnson, K. L., Currie, G., and Bacic, A. 2000. The classical arabinogalactan protein gene family of Arabidopsis. Plant Cell 121751-1767.

Schultz, C. J., Rumsewicz, M. P., Johnson, K. L., Jones, B. J., Gaspar, Y., and Bacic, A. 2002. Using genome resources to guide research directions. The arabinogalactan protein gene family as a test case. Plant Physiol. 129:1448-1463.

Seifert, G. J., and Roberts, K. 2007. The biology of arabinogalactan proteins. Annu. Rev. Plant Biol. 58:137-161.

Showalter, A. M. 1993. Structure and function of plant cell wall proteins. Plant Cell 5:9-23.

Showalter, A. M. 2001. Arabinogalactan-proteins: Structure, expression and function. Cell. Mol. Life Sci. 58:1399-1417

Showalter, A. M., Keppler, B., Lichtenberg, J., Gu, D., and Welch, L. R. 2010. A bioinformatics approach to the identification, classification, and analysis of hydroxyproline-rich glycoproteins. Plant Physiol. $153: 485-513$

Silvester, W. B., and McNamara, P. J. 1976. The infection process and ultrastructure of the Gunnera-Nostoc symbiosis. New Phytol. 77:135141.

Silvester, W. B., and Smith, D. R. 1969. Nitrogen fixation by GunneraNostoc symbiosis. Nature 224:1231.

Silvester, W. B., Parsons, R., and Watt, P. W. 1996. Direct measurement of release and assimilation of ammonia in the Gunnera-Nostoc symbiosis. New Phytol. 132:617-625.

Smallwood, M., Yates, E. A., Willats, W. G. T., Martin, H., and Knox, J. P 1996. Immunochemical comparison of membrane-associated and secreted arabinogalactan-proteins in rice and carrot. Planta 198:452-459.

Snogerup, L. 1997. Plasma membrane arabinogalactan proteins. Ph.D. the- 
sis, Department of Plant Biochemistry. Lund University, Lund, Sweden. Tandeau de Marsac, N., and Houmard, J. 1988. Complementary chromatic adaptation: Physiological conditions and action Spectra. Pages 318-328 in: Methods in Enzymology. L. Packer and A. N. Glazer, eds. Academic Press, London.

Towata, E. M. 1985. Mucilage glands and cyanobacterial colonization in Gunnera kaalensis (haloragaceae). Bot. Gaz. 146:56-62.

van Hengel, A. J., and Roberts, K. 2003. AtAGP30, an arabinogalactanprotein in the cell walls of the primary root plays a role in root regeneration and seed germination. Plant J. 36:256-270.

van Hengel, A. J., Tadessel, Z., Immerzeel, P., Schols, H., van Kammen, A., and de Vries, S. C. 2001. N-Acetylglucosamine and glucosaminecontaining arabinogalactan proteins control somatic embryogenesis. Plant Physiol. 125:1880-1890.
Waterhouse, A. M., Procter, J. B., Martin, D. M. A., Clamp, M., and Barton, G. J. 2009. Jalview version 2-A multiple sequence alignment editor and analysis workbench. Bioinformatics 25:1189-1191.

Yates, E. A., Valdor, J.-F., Haslam, S. M., Morris, H. R., Dell, A., Mackie, W., and Knox, J. P. 1996. Characterization of carbohydrate structural features recognised by anti-arabinogalactan-protein monoclonal antibodies. Glycobiology 6:131-139.

Zdobnov, E. M., and Apweiler, R. 2001. InterProScan-An integration platform for the signature-recognition methods in InterPro. Bioinformatics 17:847-848.

Zilliges, Y., Kehr, J.-C., Mikkat, S., Bouchier, C., Tandeau de Marsac, N., Börner, T., and Dittman, E. 2008. An extracellular glycoprotein is implicated in cell-cell contacts in the toxic cyanobacterium Microcystis aeruginosa PCC 7806. J. Bacteriol. 190:2871-2879. 